\title{
An Analysis of the Supports and Constraints for Scientific Discussion in High School Project-Based Science
}

\author{
NONYE M. ALOZIE, ELIZABETH BIRR MOJE, JOSEPH S. KRAJCIK \\ School of Education, University of Michigan, Ann Arbor, MI 48109-1259, USA
}

Received 27 November 2008; revised 23 June 2009; accepted 4 July 2009

DOI 10.1002/sce.20365

Published online 9 September 2009 in Wiley InterScience (www.interscience.wiley.com).

\begin{abstract}
One goal of project-based science is to promote the development of scientific discourse communities in classrooms. Holding rich high school scientific discussions is challenging, especially when the demands of content and norms of high school science pose challenges to their enactment. There is little research on how high school teachers enact scientific discussions using project-based science curricula, making the kinds of necessary embedded supports unclear. To address that gap in the research literature, this study analyzed curriculum supports and embedded educative features for the enactment of science discussions in one high school project-based science curriculum. Through a study of teacher enactment and a comparison of the curriculum discussion supports, we observed that while teachers increased their attempts to engage in inquiry-based discussion practices where supports were offered, they relied on heavily on traditional "recitation" formats, demonstrating that existing curricular supports were not developed enough to support dialogic classroom interactions. We hypothesize about conditions that may contribute to the pervasiveness of typical discourse practices in high school science discussions. We argue for expanded curricular discussion supports for teachers and design research on developing discussions in high school project-based science classrooms to examine how such supports are taken up, dismissed, or modified in practice. (C) 2009 Wiley Periodicals, Inc. Sci Ed 94:395-427, 2010
\end{abstract}

Correspondence to: Nonye Alozie; e-mail: cinny@umich.edu

The unit described here was designed as part of the Education for Community Genomic Awareness project. Unit materials are available for download at www.hi-ce.org.

Contract grant sponsor: National Institutes of Health, Science Education Partnership.

Contract grant number: R25RR022703.

Any opinions expressed in this work are those of the authors and do not necessarily represent either those of the funding agency or the University of Michigan. 


\section{INTRODUCTION}

Calls for reform in science education (National Research Council, 1996, 2000) have inspired the integration of inquiry-based practices in science classrooms via project-based science (Blumenfeld, Marx, \& Harris, 2006; Krajcik et al., 1998; Polman, 2000). Many scholars have investigated the effects of social aspects of elementary and middle school classroom environments on learning (Greeno \& Middle School Mathematics Through Applications Project Group, 1998) and argue that learning environments and activities should be organized to include opportunities for acquiring basic skills, knowledge, and intellectual activity as contributions to students' development. Through such opportunities, students become effective participants in the meaningful social practices of their learning communities in and out of school. As students talk about scientific phenomena with each other and their teacher, they can be socialized into the culture and discursive practices of science as a discipline (Barron et al., 1998; Krajcik \& Blumenfeld, 2006; Krajcik et al., 1998; Polman, 2004; Singer, Marx, Krajcik, \& Chambers, 2000).

Thus, project-based environments can provide students with opportunities for the exchange of ideas to support engagement and learning. However, studies have shown that during project-based science instruction, classroom discussions can be problematic as students struggle to navigate through several types of classroom and scientific discourses (Moje, Collazo, Carillo, \& Marx, 2001). This may be particularly true at the middle and high school levels. For example, discussion may be challenging due to the increasing abstraction of scientific concepts as students progress through the upper grades (Solomon, van Der Kerkhof, \& Moje, in press). In addition, the norms and conventions of high school classrooms - where a "pedagogy of telling" (Sizer, 1984) continues to dominate (O'Brien, Stewart, \& Moje, 1995) - may make the enactment of discussion difficult. Finally, high school students' motivation to engage in discussion may be shaped by years of experiencing a pedagogy of telling or of struggle in learning science, particularly for students who have been traditionally marginalized or denied opportunities to learn science in meaningful ways. As a result, students may either be suspicious of the request to discuss their ideas or may simply not know how to discuss in meaningful and generative ways.

Thus, there is still much to be learned about supporting the development of scientific conversations and discourse in secondary school project-based science classrooms. In particular, it is not clear how teaching practices that focus on discussion and at the elementary and middle school levels work in high school project-based science. It is also unclear whether high school teachers can make use of the same sorts of curricular supports that lower grades teachers value, or whether curricular materials need to attend to the unique features of high school science and classroom norms. The purpose of this study, then, is to understand how high school biology teachers and students engage in discussion and whether embedded curricular supports are sufficient for promoting the enactment of inquiry-based discussions in high school project-based science classrooms.

A series of general questions drove our work: What kinds of discussions took place in the classroom? How did discussions look when supports were embedded in curriculum materials? Did discussions resemble linear initiate-response-evaluate (IRE) interactions or interactive conversations involving several members of the classroom? If particular discussion practices prevailed, then what aspects of classroom arrangements might explain the tendency to engage in such practices? To the point of curricular design experimentation, how might curricular materials be modified to better support teachers in developing dialogic, inquiry discussions? In our analysis, we operationalized these questions by asking specifically (a) What are patterns of teacher-student interactions in relation to the embedded curricular 
supports? and (b) Do teacher and student interactions include discussion practices that are supported by research evidence?

Before turning to an in-depth presentation of the findings related to these questions, we offer a brief review of the theoretical and empirical perspectives that guided our work.

\section{REVIEW OF THEORETICAL AND EMPIRICAL PERSPECTIVES ON DISCUSSION IN INQUIRY SCIENCE}

Our interest in the enactment of discussions in project-based science required a review of two bodies of literature. First, we were interested in what extant research says about how people are thought to learn science through discussion. That work was framed by theories and research on how discussions in science classrooms are shaped by scientific, instructional, and everyday discourses (Moje et al., 2001), or what Gee (1996) would refer to as Discourses, using the upper-case D to signal not only a stretch of language, but also ways of knowing, doing, talking, reading, and writing. Second, we reviewed studies that examined teaching practices that might support rich discussions about science and considered how project-based science curriculum materials might support teachers in carrying out these teaching practices.

\section{The Discourses of Science Learning Through Discussion}

Many scholars of science and science education have argued that scientific knowledge does not automatically arise out of independent exploration of the physical world, but is an expression of a particular way of knowing the world that developed through the enculturation into particular practices of a community of scientists (Crawford, Kelly, \& Brown, 2000; Kelly \& Green, 1998; Lemke, 1990; Magnusson, Palincsar, \& Templin, 2004). In an ideal inquiry-oriented science classroom, students learn the practices and discourse of scientists, or their ways of knowing, doing, believing, acting, reading, and writing (Gee, 1996), even as they also learn to analyze those practices. Blumenfeld, Marx, Patrick, Krajcik, and Soloway (1997) claimed that by entering into the discourse of science, for example, students learn ways of knowing in the discipline, what counts as evidence, and how ideas are validated and communicated. In project-based science classrooms, the creation of discourse communities is argued to help students ask questions, write explanations, form conclusions, make sense of information, discuss data, and present findings (Krajcik $\&$ Blumenfeld, 2006). The challenge, however, is to integrate scientific discourse into the learning experiences of students. Curriculum materials that promote discourse in science are not often explicit about how to enact rich, open-ended scientific discussions in projectbased classrooms (Moje et al., 2001). Specifically, Moje et al. show that the enactment of project-based classroom materials draws on a variety of discourses, including the discourses of science, instruction, and everyday life. Within the science classroom, several discourses compete with one another, and when teachers and students are not explicitly supported in navigating those discourses, the creation of a scientific discourse community in the classroom becomes challenging (Moje et al.).

\section{Monologic and Dialogic Interactions in Inquiry-Based Instruction}

In addition to the challenges of negotiating multiple discourse communities, classroom discussions can be difficult because of the norms for what has come to be thought of as discussion in classrooms. Although discussions rely on a variety of interactional structures, 
classrooms - especially at the secondary level— tend to be dominated by patterns of teacher initiation of ideas, followed by student response and teacher evaluation. This IRE practice (Mehan, 1979; Tharp \& Gallimore, 1991) is also sometimes referred to as recitation (Alvermann, Dillon, \& O'Brien, 1987) or triadic dialogue (Lemke, 1990). Lemke claimed that in triadic dialogue the teacher tends to control initiating exchanges, setting the topic, and controlling the direction in which the topic develops. Within this structure, students have little control directing the discussion or contesting teacher prerogatives (Lemke).

In this style of classroom communication, information is transmitted from teacher to students and there is little opportunity for student contributions (Wells \& Mejia-Arauz, 2006); the discussion pattern can thus be considered monologic or authoritative (Scott, Mortimer, \& Aguiar, 2006), despite the fact that multiple people speak in the exchanges. Although monologic communication has its purpose and value, it does not align with the discursive goals of project-based science (Polman, 2004), nor does it support the conceptual goal of students constructing knowledge (Wells \& Mejia-Arauz, 2006). Students learning science (and any other discipline) need opportunities to discuss in settings where speakers and listeners attempt to understand the perspectives of the other, thereby promoting student participation in inquiry, discourse, and reasoning.

In dialogic interactions, the teacher encourages students to put forward ideas and explore and debate different points of view, in line with goals of project-based science. In addition, students' responses are often tentative suggestions based on open or genuine questions, spontaneous, and expressed in whole phrases or sentences (Chin, 2007). As students develop cultural skills of negotiation and questioning skills in science, they become active members of the scientific community while continuing to remain learners with agency, rather than passive receptacles (Polman, 2004). Jimenez-Aleixandre, Rodriguez, and Duschl (2000) found, for example, that when the high school students were given opportunities to solve problems, discuss science, and talk science, they used a variety of communication operations, such as argumentative and epistemic, thereby developing additional nonconceptual skills of communication and discussion. Although students may respond to opportunities of problem solving, teacher instruction and interactions play a critical role in the discussion (Caravita \& Hallden, 1994).

Developing these dialogic discussions in the project-based science classroom is challenging, however, especially at the upper grade levels, because spontaneous engagement in scientific talk among students is rare (Lemke, 1990; Moje et al., 2001). Indeed, Vygotsky (1986) argued that one of the primary goals of learning was to move from spontaneous thinking to the scientific thinking (although Vygotsky referred to scientific in the way current scholars might now use academic or schooled). In other words, Vygotsky posited scientific or academic thinking - and one might imagine the discursive practices that accompany such thinking - as a matter of formal learning, which happens over time, not something that people routinely experience in everyday life (although it should be noted that dialogic discussions about everyday, or spontaneous, concepts may well be experienced routinely). For many secondary school students, however, schooled in monologic or authoritative discourse practices over time in classrooms, dialogic discussions about disciplinary ideas have been rare; as a result, they are not skilled in such discussion practices, and neither are their teachers (Nassaji \& Wells, 2000). In fact, Nassaji and Wells claim that even with efforts of fostering dialogic discussions in science classrooms, triadic dialogue continues to be the dominant discussion structure. Owing to the prevalence of triadic dialogue in project-based classrooms, teachers need substantial support in finding ways to integrate and manage competing discourses (Moje et al., 2001) and move classroom discussions toward dialogic interactions. 


\section{Instructional and Interactional Discourses: Practices of an Inquiry-Based Discussion}

To make discussions more dialogic and inquiry-based, Nassaji and Wells (2000) argued that altering the evaluative portion of the triadic dialogue to include nonjudgment evaluations, such as follow-up questions (IRF), moves discussions toward dialogic conversations. In addition, Chin (2007) showed that using initiating questions rather than recall questions can also promote dialogic interactions. Chin argued that initiating questions work well for dialogic discussion because they require students to confront and evaluate prior knowledge.

One important feature of inquiry-based discussions is students' ability to make knowledge explicit. Within project-based science discussions, students are required to weigh evidence presented by several of their classmates, looking for the most appropriate solution based on scientific reasoning and theory. Thus, it is important to carefully select one's tools of expression so that the significance of one's work is best signaled to the community (Magnusson et al., 2004). The use of evidence explained by scientific reasoning may act as a communication tool, help demonstrate student knowledge of science, and contribute to the dialogic nature of a discussion (Kuhn, Kenyon, \& Reiser, 2006; McNeill, Lizotte, Krajcik, \& Marx, 2006). Students should not only "get the right answer" but also learn to participate in a discussion involving several classmates with potentially different viewpoints and ideas, while using evidence and scientific reasoning to justify their thoughts and ideas.

In inquiry-based discussions, the development of classroom norms must be an ongoing process between the teacher and students. Teachers may help students develop collaboration skills, including turn taking, listening, and respecting others (Krajcik, Czerniak, \& Berger, 2002). The teacher also manages the discussion by avoiding a highly competitive environment and by helping students see that divergent results are a product of activity (Magnusson et al., 2004).

Magnusson et al. (2004) describe three dimensions of teacher activity that encourage student enculturation into a community of practice. In the first dimension, teachers establish and maintain the conversational norms of everyday discourse through proper etiquette. In the second dimension, the teacher supervises and manages the intersection of everyday and scientific discourses by helping students move back and forth, and make connections between everyday and scientific language. In this dimension, teachers can provide a metascript, "revoice' student responses, serve as the collective memory for the class, and provide additional ideas that otherwise may not have been said, also called "seeding" (Magnusson et al.). In the third dimension, teachers give differential responses to students who appropriate scientific norms.

The above-mentioned studies have identified several strategies to promote dialogic discussions in science classrooms. Using this literature, we created a framework of researchbased instructional strategies to increase student engagement in whole-class discussions (see Table 1). We have grouped them into four categories: (a) making knowledge explicit through claim, evidence, and reasoning, (b) asking questions that avoid evaluative teacher responses, (c) supporting students in communication, and (d) discussion. Although this research-based framework did not guide our development of the curriculum, it provided criteria for the current analysis and future revisions of the curriculum. It also served as a standard as we observed the teachers during enactment.

\section{Curriculum Materials and Classroom Discussions}

Literature in teacher learning suggests that curriculum materials should include supportive elements to be educative for teachers and promote teacher learning (Davis \& Krajcik, 
TABLE 1

\section{Discussion Practices Table: Four Categories of Inquiry-Based Discussion Practices Based on Educational Research}

\begin{tabular}{|c|c|}
\hline Discussion Practices & Description \\
\hline 1. Making knowledge explicit & $\begin{array}{l}\text { 1. How do students use evidence and scientific reasoning } \\
\text { to support claims? }\end{array}$ \\
\hline $\begin{array}{l}\text { 2. Asking questions and } \\
\text { providing nonevaluative } \\
\text { follow-ups }\end{array}$ & $\begin{array}{l}\text { 2A. How do teacher questions incorporate student } \\
\text { reflection, negotiation, use of claim, evidence, } \\
\text { reasoning, and the confrontation of prior knowledge? } \\
\text { 2B. How does the teacher extend the discussion with } \\
\text { follow-up questions? }\end{array}$ \\
\hline $\begin{array}{l}\text { 3. Supporting student } \\
\text { communication }\end{array}$ & $\begin{array}{l}\text { 3A. What roles did students play during discussions? } \\
\text { 3B. What type of public document did the teacher provide } \\
\text { to keep track of the goals and points made? }\end{array}$ \\
\hline 4. Discussion etiquette & $\begin{array}{l}\text { What kinds of classroom norms are established in the } \\
\text { class concerning discussions? } \\
\text { 4A. Teacher as facilitator and manager of discussion } \\
\text { 4B. Teacher works at intersection of everyday language } \\
\text { and scientific discourse (metascript, revoicing, } \\
\text { collective memory, seeding, restating driving } \\
\text { question, and using prompts } \\
\text { 4C. Differential response for appropriate uses of } \\
\text { language and actions }\end{array}$ \\
\hline
\end{tabular}

2005; Fishman \& Davis, 2006), but it is not often that curriculum materials contain such components (Kesidou \& Roseman, 2002). Davis and Krajcik (2005) developed design heuristics that provide guidance in the development of curriculum materials intended to promote teacher and student learning by providing appropriate and relevant activities, the rationale behind the recommended activities, and classroom adaptation strategies. Because Moje et al. (2001) argue that competing discourses in project-based science classrooms contribute to the complexity of the development of discourse communities, we advocate for an increase in teacher supports as a way to potentially alleviate the difficulty.

In this study, we applied the heuristics to the curriculum materials under investigation as a way to analyze the educative nature of curricular supports for promoting scientific discussions in the classroom. According to Davis and Krajcik (2005), supports for classroom discussions are twofold. First, curriculum materials should provide suggestions and strategies to help teachers promote productive discussions among students and teachers through conversations and student artifacts. Second, curriculum materials should provide the teacher with a rationale for unit activities involving discussions. Curriculum materials are to provide teachers with justification and logic behind intended activities and discussions. Understanding the underlying principles involved in discussions allows the teacher to mold and change discussions as necessary.

In sum, student participation in dialogic discussions is one-way project-based science, promotes the development of inquiry skills and developing understanding of core ideas, such as learning and appropriating scientific ways of knowing, using evidence to articulate understanding of science concepts, and developing questioning and listening skills. Although research shows that the use of a variety of discussion practices enhances the quality of classroom discussions, engaging students in scientific discussions is a 
complex process. The addition of rationales and enactment strategies as educative curriculum features can help teachers enacting project-based curriculum materials. As the demands for increased science inquiry skills continue to grow, curriculum development will have to adjust to meet those demands. Having an understanding of the nature of complex social interactions associated with high school discussions and of how to support teachers in the midst of the discursive complexity can give curriculum developers better insight in the design of project-based materials that encourage the enactment of discussions through inquiry-based practices.

\section{RESEARCH DESIGN AND METHODS}

The design of our study was guided by the review of the literature offered above, as well as by learning theories that shaped how we studied the uptake of discussion supports in two high school biology classrooms. In what follows, we outline the theories that shaped our methods of data collection and analysis.

\section{Sociocultural Theory, Science Learning Theory, and Design Experimentation}

Sociocultural Theory. The work of our entire research and development group is informed by sociocultural theories of teaching and learning, which suggest that teaching and learning are always situated in and mediated by particular contexts and relationships with other people. In addition, sociocultural theory argues that learning is a result of many kinds of tool use, with tools including objects such as pencils or electronic technologies; language practices such as discussion; and cultural models that shape the ways people talk, read, write, or know (see Wertsch, 1995, on primary, secondary, and tertiary tools). Sociocultural theory demands that research be designed to capture and analyze the events and enactments of particular people as they use various tools in particular contexts.

Science Learning Theory and Design Experimentation. Inquiry- or project-based science approaches fit neatly within a sociocultural theoretical framework. The goal of inquiry science (or any project-based curriculum) is that student learning is framed and motivated by real-world questions that are of interest to learners. The features of inquiry science curricula generally include (a) driving questions anchored in real-world problems; (b) investigations and artifact creation; (c) collaboration among students, teachers, and others in the community; and (d) use of technological tools (Krajcik et al., 1998). Because these features are dependent on actual enactments, it is critical that research be conducted in the settings where the science is being learned. It is also critical that before attempting to take curricular designs to a larger scale, the curricula be examined in classroom settings, with a focus on how the materials support or constrain teacher enactments and students learning. Thus, our entire research design is framed by principles of design experimentation in project-based science, which focus on understanding how the curriculum, as imagined by developers, gets put into action in feasible and meaningful ways.

\section{Materials, Contexts, and Participants}

Curriculum Materials. We developed a high school curriculum for 9th/10th graders designed to support students' understanding of molecular genetics and genomics. Although 
the materials were designed around National Benchmarks and Standards (American Association for the Advancement of Science, 1993), we also inquired with genomics experts to identify new and important ideas in genomics and genetics that were more current than the Benchmarks and Standards. Our project-based materials used How SIMILAR or DIFFERENT Are We? as a contextualizing focus or driving question (Krajcik \& Blumenfeld, 2006). The question asked students to make comparisons at many biological levels between themselves and other humans and themselves and other animals. Since hands-on manipulation of genetic data is limited, the curriculum materials promoted discussions to facilitate synthesis of scientific concepts and sense making. This inquiry-based approach to genetics and genomics instruction requires teacher supports for engaging students in discussions that encourage students to participate in a scientific community through sharing, rebutting, and justifying ideas through scientific evidence and reasoning.

We offer a summary of embedded curricular supports in Table 2 to provide a holistic view of our data and show the curricular context of the teachers' enactments. The curriculum materials encouraged the teachers to engage the students in discussions on 36 different occasions, spread over 6 lessons. The curriculum described discussions as an opportunity for students to make sense of the subject matter presented through activities, texts such as readings and video, and lectures. Table 2 is holistic views, lesson by lesson, of how discussions were organized in the curriculum and how each teacher enacted them.

Participants. The How SIMILAR or DIFFERENT Are We curriculum materials were enacted in 9th- and 10th-grade classrooms in two urban high schools in a large Midwestern city during the 2005-2006 school year. The high school science coordinator for the district selected the teachers based on teacher availability and interest. Ms. Lewis used the curriculum in two 10th- and 11th-grade general biology classes. Mr. Kaine enacted the curriculum in five 9th-grade general biology classes. The two participating teachers differed in their experience with the students and taught different grade levels and were enacting the curriculum for the first time. At the time that the unit was enacted, the 9th-grade teacher, Mr. Kaine, had been teaching for approximately 5 years and the 10th-grade teacher, Ms. Lewis, had been teaching for 11 years and taught a higher achieving biology class. Both teachers are Caucasian. All school and teacher names are pseudonyms.

The classrooms were representative of the schools' populations each of which is composed of approximately 97\% African American students. Of the 177 students who used the curriculum, 78 students and their parents agreed to participate in the program by allowing us to videotape them in class and review their classwork and tests.

According to state standardized test scores, $11 \%$ of students at Kellog High School (where Mr. Kaine taught) performed at proficient levels in mathematics and $46 \%$ reached proficiency in reading. Kellog recorded a 70.0\% economically disadvantaged enrollment. Mulane High School, where Ms. Lewis taught, saw $15.5 \%$ of its students reach proficiency in mathematics and $55.5 \%$ in reading. Forty-two percent of the students at Mulane qualified as economically disadvantaged.

\section{Methods of Data Collection}

Our research group collected data in the spring semester of the 2005-2006 school year. The data consisted of videotapes of classroom enactment, the teacher guide, student guides (student workbooks), pre- and posttests, teacher and student feedback, and surveys. For this 
TABLE 2

Trends in Curricular Supports and Teacher/Student Enactment

\begin{tabular}{|c|c|c|c|c|c|c|}
\hline Lesson & Rationale & Strategies & IRE & $\begin{array}{l}\text { Open } \\
\text { Ended }\end{array}$ & $\begin{array}{l}\text { Teacher-Initiated } \\
\text { Research-Based } \\
\text { Inquiry Practices }\end{array}$ & $\begin{array}{l}\text { Student-Initiated } \\
\text { Research-Based } \\
\text { Inquiry Practices }\end{array}$ \\
\hline \multicolumn{7}{|c|}{ Mr. Kaine } \\
\hline 1 & $\sqrt{ }$ & $\sqrt{ }$ & $\sqrt{ }$ & & $\sqrt{ }$ & \\
\hline 2 & & & $\sqrt{ }$ & & $\sqrt{ }$ & \\
\hline 3 & & & $\sqrt{ }$ & & $\sqrt{ }$ & \\
\hline 4 & & & $\sqrt{ }$ & & $\sqrt{ }$ & \\
\hline 5 & $\sqrt{ }$ & $\sqrt{ }$ & & $\sqrt{ }$ & $\sqrt{ }$ & \\
\hline 6 & $\sqrt{ }$ & $\sqrt{ }$ & $\sqrt{ }$ & & & \\
\hline Total & 3 & 3 & 5 & $\begin{array}{l}1 \\
\text { Us. Lewis }\end{array}$ & 5 & 0 \\
\hline \multirow{2}{*}{\multicolumn{7}{|c|}{$\begin{array}{l}1 \\
2\end{array}$}} \\
\hline $\begin{array}{l}2 \\
3\end{array}$ & & & & & & \\
\hline 4 & & & $\sqrt{ }$ & & $\sqrt{ }$ & \\
\hline 5 & $\sqrt{ }$ & $\sqrt{ }$ & & $\sqrt{ }$ & $\sqrt{ }$ & \\
\hline 6 & $\sqrt{ }$ & $\sqrt{ }$ & & $\sqrt{ }$ & $\sqrt{ }$ & \\
\hline Total & 2 & 2 & 1 & 2 & 3 & 0 \\
\hline
\end{tabular}

This table shows whether discussions in each lesson in the curriculum were supported with a rationale and/or enactment strategies and the types of discussions that ensued. The table is a summary to show trends within and across teachers. The table shows the lesson number (column 1), the presence of a rationale in the curriculum (column 2), the presence of enactment strategies in the curriculum (column 3), the types of discussions for each lesson (columns 4 and 5), whether the teacher initiated research-based inquiry practices (column 6), and whether the students initiated research-based inquiry practices.

Research-based inquiry-practices include the following: Open-ended initiation questions, Follow-up questions, Evidence based responses, Revoicing, Reflective Toss, Metascript, and Seeding. Blank: Unobserved lesson

study, analyses focused on videos of the classroom enactment, using the written curriculum to track when curriculum-embedded supports were or were not used. The video showed the interactions between the teacher and students, whereas the curriculum gave insight to how teacher enactment was supported. Because this study made several iterations of enactment analysis and curriculum examination, data collection and analysis occurred throughout the duration of this study.

To understand the kinds of verbal exchanges that took place in the classroom, we analyzed several portions of discussions. Because video notes revealed a prevalence of IRE recitation, we chose discussions that were long enough to demonstrate the instructional and interactional discourse patterns. Subsets of five discussions were used for detailed discourse analysis (Nassaji \& Wells, 2000; Wells \& Mejia-Arauz, 2006). In this analysis, we characterized the discussions based on their interaction patterns to understand participant structures and to identify discussion practices used by the teacher and/or students.

Owing to the staggered enactment by the teachers, we were unable to observe several of Ms. Lewis's enactments. For the discourse analysis of the discussion subsets, I observed lessons from different time periods of the remaining enactments. 


\section{Methods of Data Analysis}

Video Analysis. How Were the Materials Enacted? To understand what enacted discussions looked like, I reviewed 28 videotapes in real time without playback and wrote the equivalent of fieldnotes (Erickson, 1986) paying particular attention to discussions. From the video notes, we identified overall classroom discourse trends (Strauss \& Corbin, 1998) by coding discussions as IRE or open ended. During the second round of watching the videotapes, we documented whether research-based discussion practices (see Table 1 for discussion practices table) were used by teachers and students in classroom discussions. When watching for teacher and student discussion practices, we acknowledged follow-up questions, revoicing, reflective toss, metascript and seeding, as research-based practices to help enhance the progression of discussions in project-based classrooms.

We transcribed the selected discussions verbatim and used discourse analysis (Nassaji \& Wells, 2000; Wells \& Mejia-Arauz, 2006) to analyze discussion patterns. The analysis of the discussions focused on the structure of the discussions and the function each move contributed to the discussion sequence (see Appendixes B and C for full discourse analysis). During our analysis, we looked at the types of questions teachers and students asked, the kinds of responses given by teachers and students, the kinds of evaluations or follow-ups given by the teachers, and the participation structures.

Comparison of Teacher Guide and Video of Teacher Enactment. We began by examining discussion practices. We performed a side-by-side comparison of the curricular discussion supports and the video notes to show the discourse patterns and discussion practices teachers used during discussions. In Table 2, we made comparisons between the presence of curricular supports (rationale and strategies in columns 2 and 3), the types of discussion that ensued (columns 4 and 5), and whether discussion moves were teacher or student initiated (columns 6 and 7).

Next we turned to discourse patterns. To understand the kinds of speaking patterns that took place when supports were given, we performed a second comparison between the transcripts and the curricular discussion supports to understand the characteristic discussion patterns. In Appendix B and C, we provided transcripts and the discourse analysis for the excerpts.

During this portion of the analysis, we also documented and categorized whether a rationale for suggested discussions were written in the curriculum materials and whether strategies were given to help the teacher enact the discussions in real time. For example, in Lesson 2 of the curriculum, the teachers are asked to have a class discussion on what makes melanin, the pigment that gives skin its color. The materials made reference to overhead slides used in class and asked the teacher to do the following:

Slide 2.1: Remind the students about what they learned about skin color. Make the connection from visual of whole body trait, to tissue, to cells. This connection is one of the common places students struggle when learning this material. Introduce the question: How is melanin made inside the melanocytes? Hopefully students' work on the previous activity will help them to think of proteins.

In the above example, the curriculum materials gave a rationale for the discussion, saying that the connection between whole body traits and cells is difficult for students to understand. From this description, the teacher may have an understanding of why this discussion is 
important for student conceptual understanding, but does not know how to generate ideas from the students, sustain the discussion, promote student-student communication and intersubjectivity, or establish roles of participation during discussions. Furthermore, the language of the question does not invite hypotheses (e.g., it does not read, "How do you think melanin might be made inside melanocytes?"). Instead it asks the question in a way that implies a definitive answer, signaled by the use of "is made" and the lack of any hedging or speculative language. Indeed, the question is not really a question for openended discussion because in fact, it does have an answer already established by scientific investigation. In this case, we would categorize this discussion as supported with a rationale with no enactment strategies and a weak discussion starter.

In contrast, an example of a good discussion starter is in Lesson 6, where the curriculum explicitly stated that the discussion rationale is to have a preliminary idea of what the genome is and how large and complex it is. It explains that the teacher should connect the students understanding of what a gene is to the idea that it is just a small part of the genome. It goes on to say that the teacher should press for understanding and try to get the student to generate more elaborate responses. The curriculum also suggested strategies to help the teacher accomplish the rationale. For example, a suggested strategy was that the students work in pairs to bring together ideas and prepare them for a larger class discussion. In this case, we would categorize this discussion as supported with both rationale and enactment strategies and a strong discussion starter.

In Table 2, we summarized for each lesson and teacher the supports provided by the materials, the general trend of discussion, and the frequency of teacher- and studentinitiated discussion practices. The table shows the trend of discussion types in relation to curricular supports for each teacher. Appendix A gives a discussion-by-discussion account of written supports and subsequent enactment discussion practices. Our analysis of the curriculum materials and the discussion enactment gave insight to what curricular supports alone may or may not enable in terms of how dialogic discussions in science classrooms progress.

Student Outcomes. To assess the impact of the curriculum enactment, we collected data from pre- and posttests collected from a total of 65 students who completed both tests. We consider these to be contextual data, used not to determine the efficacy of a treatment, but to allow us to ascertain what students learned and what areas seemed to challenge both students and teachers. The pre/posttests contained multiple-choice and open-ended items. We scored the open-ended items using a rubric designed to evaluate depth of content understanding. Student gains were analyzed using a paired $t$-test.

\section{FINDINGS}

In this section, we present the results from our analyses of whether embedded curricular supports were sufficient for promoting the enactment of inquiry-based discussions in high school project-based science classrooms. As mentioned earlier, we addressed the following questions: (a) "What are patterns of teacher-student interactions as compared to the presence of embedded curricular supports?" and (b) "Do teacher and student interactions include discussion practices supported by research?"

Our results indicate teacher difficulty in balancing student engagement in dialogic versus monologic or authoritative discussion interactions (Scott et al., 2006); namely, encouraging 
student-student communication, limiting teacher centrality during discussions, sustaining interactions among students, and between students and teachers. In this study, Mr. Kaine seemed to struggle more with dialogic and authoritative tensions; IRE recitation was much more common during his enactment than in Ms. Lewis's. Through detailed discourse analysis and a review of the literature, we offer explanations for the IRE patterns observed.

Before turning to our findings regarding classroom discussion data, however, we begin by reporting student pre- to posttest gains as a way of establishing the ground for the claims we will make about discussion practices. The analysis of the scores from the pre- and posttests using a paired $t$-test indicated that students made statistically significant gains ( $p$ value of .001). Answers to open-ended items indicated that we made progress in helping students understand the relationship between genes and proteins (14.3\% gain and $p$ value of .00), but students still confused key concepts such as the relationship between genes and chromosomes. Students also made progress at incorporating molecular mechanisms into explanations of phenotypes, but struggled with incorporating all the levels of biological organization into their explanations. In sum, although students struggled with some of the genomics content, the gains made in the pre- and posttests show that during the enactment of the curriculum, students developed a knowledge base that could allow them to use and explore ideas during classroom discussions.

\section{Mr. Kaine's Discussion Practices}

Although Mr. Kaine asked questions that required student elaboration, in each case he eventually evaluated student responses and expanded the answers for them, making IRE recitation the most dominant discourse pattern in his classroom discussions. Many times, students gave one-word responses, and Mr. Kaine accepted them without encouraging elaboration, further explanation, or additional input from other students. Students were not asked to explain their thoughts or the biological mechanisms behind their answers, as illustrated in this excerpt ${ }^{1}$ :

1 Mr. Kaine: Now, you can always start thinking about this, mouse to

2 human, as similar and different. What would be a similarity that you can

3 see right there, between a human and a mouse? (Referring to external

4 differences)

5 Student: Eyes, eyes.

6 Mr. Kaine: Two eyes. So you would write two eyes. . . (write on board)

7 Are the eyes the same? They are about the same size, but adult humans

8 have bigger eyes than adult mice, right? But you can start writing down

9 similarities and differences, external structures.

10 Student: They have four legs.

11 Mr. Kaine: They have four limbs. L-I-M-B. Right? They have front paws

12 and back paws. Back legs. Now we have legs and arms, we call them.

13 Now what's different about how they move?

14 Several students speak at once: They walk on all fours.

15 Mr. Kaine: They walk on all fours and we walk on the rear ones.

\footnotetext{
${ }^{1}$ We have omitted technical marks and symbols for pauses and intonations in the excerpt. We focus on turn-taking sequences, the types of questions asked, the types of responses given, and the response lengths.
} 
This excerpt illustrates typical teacher-student interaction patterns in Mr. Kaine's classroom: Mr. Kaine asked a question that requires analysis on the part of the students, although the nature of the analysis could revolve around low-level anatomical similarities and differences or higher level behavioral and cognitive similarities and differences. One student responded to Mr. Kaine's question with anatomical similarities, using only the one-word response "eyes," in line 5, and Mr. Kaine took up the one-word response and elaborated on it for the student. This pattern recurs throughout the exchange and, indeed, throughout all of Mr. Kaine's classroom interactions, regardless of the nature of the question posed.

For example, the following excerpt stems from a discussion about sickle cell disease (see Appendix B for a detailed discourse analysis). Although the curriculum suggested that the teacher hold a discussion, no written supports in the form of rationale or enactment strategies were provided. To initiate the discussion, the teacher asked the students questions regarding a video they watched the previous day. After watching the video, Mr. Kaine asked his students to answer questions about different biological levels of sickle cell anemia. Our analysis indicates that Mr. Kaine used the discussion to bridge student understanding of the biological levels of sickle cell anemia and the video. In this excerpt, the discussion followed IRE patterns, where the teacher asked a question, a student provided an answer, and the teacher evaluated (and extended) the response for the student:

1 Mr. Kaine: Now we look deeper, we look at the level of the protein. What

2 do we see happening inside the cell to hemoglobin protein? What's it

3 doing?

4 Grace: Multiplying? Dividing?

5 Mr. Kaine: It's not that there is more hemoglobin. It's just that the

6 hemoglobin is, has a different shape right? It's not normal hemoglobin,

7 it's mutant hemoglobin. So, you can say that, if you look at the level of

8 protein, there is one amino acid that's different. You all saw that in the last

9 figure. Right, right here? [Points to powerpoint slide] One amino acid

10 change causes the change in the shape of the hemoglobin, a small

11 difference. And then it starts doing this. Right? A small change in the

12 shape and it starts glomming together to make crystals. So, how would we

13 say that? Very simply, just the hemoglobin is different from normal

14 hemoglobin. A different shape.

15 Gary: Cuz of the amino acids?

16 Mr. Kaine: Because of that one amino acid difference. I think that would

17 be perfect. If you write down that there is one amino acid difference in the

18 hemoglobin protein, it's a mutant form of it and it doesn't work exactly

19 right, that would be your explanation at the level of the protein.

In the above sequence, Mr. Kaine started with an initiation question that required an explanation for the cause and process of protein mutations, with great potential for a rich discussion. Asking the students, "What do we see happening? What is it doing?" (lines $1-3)$, suggests that the students should provide a mechanism for a change in protein shape to cause the awkward sickle cell shape. Although the response in line 3 from Grace was a question, Mr. Kaine did not redirect the question back to the class, nor ask another student to provide an explanation. Such discussion moves can shift the source of knowledge onto the students, allowing students to use activities, scientific texts, and videos from class as sources of evidence for student explanations and responses. Rather, he maintained his authoritative 
role and maintained monologic discourse patterns by addressing the question in detail himself. According to Scott et al. (2006), authoritative discourse presents one conceptual focus, as presented by the teacher and closes opportunities for additional perspectives and ideas. Student contributions to the discussion were immediately evaluated and further explained by Mr. Kaine.

However, Mr. Kaine's move in lines 5 through 14 could be explained by what he heard in Grace's response, "Multiplying? Dividing?" (line 4). Such a response may have indicated extreme uncertainty to Mr. Kaine, given that the mechanisms Grace offered are exactly opposite mechanisms. That is, she rebounded the question back to the teacher; offering two contradicting words in the form of a question, "Multiplying? Dividing?" Neither response was correct, because the cells were not multiplying nor dividing, they were changing, as Mr. Kaine explained in the remainder of the excerpt. Mr. Kaine's decision to explain - rather than to pursue a discussion about these questions-may have been motivated by Grace's uncertain response and by the nature of the topic. That is, the question that Mr. Kaine posed has a scientifically correct answer; in a classroom situation of limited time, where student responses may suggest uncertainty, Mr. Kaine may have reasonably questioned the value of engaging in a lengthy discussion of a question with an already-established answer.

Moreover, the student move resembles the teaching strategy that Mehan (1979) refers to as choice elicitation. When teachers use choice elicitation as a teaching strategy, they offer a variety of answers, only one of which is accurate, thus providing students opportunities to think through multiple possible answers to a question. In this case, a student in the classroom has appropriated the strategy, but not as a way of fostering discussion. Contradictory student responses such as Grace's were common in Mr. Kaine's classroom. In other words, students in the classroom may have learned to provide multiple answers, hoping for one to be correct, as a strategy for avoiding classroom discussion about challenging topics. In fact, repeated observation of Mr. Kaine's class indicated that it was possible for students, as well as Mr. Kaine, to maintain IRE patterns of interaction (Candela, 1999). Candela suggested that IRE in the classroom does not necessarily guarantee power to the teacher. She shows that students can in fact shift the local power from the teacher to the students by changing who asks and answers the questions in a recitation.

In the excerpt, Mr. Kaine rejected the response and explained the protein shape for Grace and the rest of the class. Mr. Kaine used his speaking turn to provide an extended and elaborated explanation for what was happening at the protein level, maintaining the monologic IRE structure. At several points in his explanation, Mr. Kaine used phrases like "You can say" and "Right?" as if he were in agreement with the student's responses, and was helping the students formulate their responses, while in actuality, no other students participated in the process of building conceptual understanding of the content.

After Mr. Kaine provided a summary of his response in lines 12 and 14, Gary asked a clarifying question to the teacher. In this sequence, other students could have helped Gary with this question, since Mr. Kaine previously gave a detailed explanation to his own question. This could have shifted the authority from Mr. Kaine onto the students, and taken the students and Mr. Kaine closer to engaging in a dialogic discussion. Instead, Mr. Kaine evaluated the student's question as correct, and continued to tell him and the other students what to write down as responses to their questions. Similarly, in the following excerpt, Mr. Kaine misses an opportunity (line 15) to draw from a student's prior knowledge and connect the abstract concept of genetic mutation to a phenomenon experienced through 
popular culture (the news):

1 Mr. Kaine: Oh. It's a change in the DNA, which is? We say that a change

2 in the DNA is defined as what kind of thing? (Silence) When you change

3 the DNA, what's happening to the DNA?

4 Grace: Say it one more time.

5 Vana: (To Grace) If you change DNA what is happening to it?

6 Mr. Kaine: If you change the sequence of DNA, what is that called?

7 Gary: If you do what?

8 Mr. Kaine: Maybe radiation can cause it. Sometimes UV radiation. Toxic

9 chemicals. In comic books, it's usually a toxic spill that someone comes

10 across and then they become?

11 Student: Mutation.

12 Mr. Kaine: Mutant, right? There is a mutation in the DNA.

13 Gary: Oh, I saw that in the news. Some dog.

14 Student (female): What did you say to put for um, genes and DNA level?

15 Mr. Kaine: In genes and DNA level, what should we write? Does anyone

16 want to volunteer what they have?

17 Grace: The gene has changed. It's a substitution mutation.

18 Mr. Kaine: That's right. The gene has changed because of a substitution

19 mutation. Alright, take a look at this (Powerpoint) in your notebook today,

20 I want you to take about a quarter page of notes. That's 3 or 4 lines of

21 notes based on what we look at in the next few minutes. So, I want you to

22 note is that this is an animal....

In sum, Table 2 shows that of the six lessons observed in Mr. Kaine's classroom, five lessons consisted of IRE recitation in Mr. Kaine's enactment. Columns 6 and 7 of Table 2 show that throughout his enactment of the curriculum, Mr. Kaine initiated at least some aspect of several discussion practices recommended in the research literature, but that the prevalent form of discussion was monologic discourse. The data also show, however, that the curriculum was inconsistent in the amount of supports for promoting discussions and a prevalence of IRE recitation in Mr. Kaine's enactment. In addition, the table shows that Mr. Kaine initiated all interactions between the students and himself; the students did not contribute to discussions by asking questions or by addressing each other. The prevalence of IRE and teacher-initiated moves suggests teacher authority over the discussion. Through iterations of examining the curriculum materials and observing teacher enactment, we found that the curriculum infrequently provided strategies to help the teacher minimize his centrality to the discussions and promote higher levels of student participation and intersubjectivity. Owing to the challenging nature of the discussions, Mr. Kaine may have needed more than the written curriculum for support.

One of the challenges Mr. Kaine faced in generating dialogic, inquiry-based discussion is that all of the questions Mr. Kaine initiated required the students to demonstrate their knowledge of science (Moje, 1997), rather than to discuss issues or concepts in science. In other words, he maintained the role of teacher as the knowledge bearer by asking questions, evaluating responses, and supplying explanations. There are several possible explanations for this practice. One may simply be that Mr. Kaine did not know how to pose dialogic questions about abstract concepts, and the curriculum did not include enough examples of questions that could inspire dialogic discussions. Another could be that Mr. Kaine felt the pressure to cover abstract content requiring specialized knowledge, 
and his students demonstrated that they did not know the answers to his questions. In this school district, teachers are held accountable through standards and statewide assessments. Since our curriculum was a first attempt enactment, Mr. Kaine may have faced several time constraints and struggled to complete the curriculum. If Mr. Kaine did not feel that students' responses contributed to the scientific point of view, he may have not felt the need to pursue a student's response (Scott et al., 2006) with follow-up questions or evidentiary support, due to lack of time. As he worked to finish the curriculum, he may have sacrificed more open-ended discussions for content coverage, a common issue for high school teachers (Alvermann et al., 1987; Sizer, 1984; R. T. Vacca \& J. Vacca, 2004).

Moreover, students responded strategically by signaling to Mr. Kaine that they did not know the answer, perhaps knowing that Mr. Kaine would intervene and explain the correct scientific ideas. Student participation and reaction to teacher moves is an important aspect of classroom interaction and plays an important role in how the teacher uses discussion as a teaching practice. In Mr. Kaine's classroom, student responses often consisted of single words and incomplete sentences. Thus, the students and teacher together reproduced an IRE format, in large part because some of the initiating questions Mr. Kaine posed, as in the previous excerpt, was a question that only allowed for a single, correct answer. In short, there was little here to discuss dialogically, the curriculum did not offer Kaine ways to think about how to frame the question in dialogic ways, and the students helped to reproduce the monologic format with one-word responses.

\section{Ms. Lewis's Discussion Practices}

Our analysis of Ms. Lewis's enactment yielded some similar patterns of practice as evidenced in Mr. Kaine's classroom, but also included some important differences in discussion teaching practice. Similar to Mr. Kaine, Ms. Lewis struggled to encourage student-student communication, limit her central role as discussion leader, and to sustain interactions among students. However, Ms. Lewis made more attempts to promote student explanations, elaboration, and use of evidence during discussions by asking series of followup questions. Table 2 shows that a combination of rationale and strategies was consistent with Ms. Lewis's enactment of open-ended discussions, while unsupported discussions remained in IRE format. For example, in the excerpt below, the teachers were asked to engage the students in a discussion about the structure of DNA. The discussion was preceded by an activity that required the students to build a model of the DNA molecule. After the students completed the activity, the curriculum materials suggested and Ms. Lewis used a discussion to help students synthesize the information. The curriculum supported the suggested discussion with a rationale, or in this case, important content for discussion, but the curriculum developers had offered no specific strategies to enact the discussion. According to the curriculum materials, the teachers were to

share their findings with the whole class and add/change observations in their Student Guide—students revise ideas after class discussion. Students return to student guide and write in response to the following question: After the class discussion, what were the key features of DNA that your class identified?

The characteristics of DNA that students should identify are the following (ask guiding questions if students do not come up with these at first):

1. DNA is a long chain of carbon-based repeated subunits (with occasional phosphorous, nitrogen, and oxygen atoms). 
2. It is double stranded (there are two chains that come together like a zipper).

3. It is composed of only four nitrogen-containing subunits, and these subunits pair in specific ways.

In this example, the curriculum materials clearly suggested that the teachers hold a class discussion and communicated specific information to be synthesized. The teacher guide only suggested the use of guiding questions to help the students talk about the content, without providing examples of questions to ask.

Ms. Lewis's instruction often included a combination of nonevaluative and evaluative follow-ups to student responses. In many cases, Ms. Lewis asked a series of follow-up questions as a way to guide students to higher order "why" or "how" questions (see Appendix C for discourse analysis). The excerpt below shows Ms. Lewis asking follow-up questions to lead the students to a higher level question. This discussion followed a DNA model-building group activity and a video.

1 Ms. Lewis: Ok. So, if you got blue, what do you know about some other

2 parts of the DNA? Do you know what's going to be above or below blue

3 necessarily?

4 Class: No.

5 Ms. Lewis: No, not necessarily. But what do you know?

6 Effie: What will be across from it. That it won't be an orange or another

7 blue?

8 Ms. Lewis: What's always across from blue?

9 Class: (answers vary) Orange; green.

10 Ms. Lewis: Orange. Why?

11 Class: (Answers vary)

12 Theo: Opposites attract.

13 Ms. Lewis: So, you think they are opposites? Ok, do me a favor. Open

14 your books to page 5, lesson 3. Alright, you see that model of DNA?

15 Class: Yes.

16 Ms. Lewis: You see how C's and G's are always across from each other

17 and A's and T's are always across from each other?

18 Class: Mmhmm.

19 Ms. Lewis: Why? Why do you think they partner up in that way?

20 Class: (answers vary) Charge; so that it will attract to the DNA.

21 Ms Lewis: Does shape have anything to do with it?

22 Class: Yes.

23 Ms. Lewis: Right, they fit together, just like Theo just said, they fit

24 together. So C and $\mathrm{G}$ fit together and A and T fit together. So, if you have

25 an A on this side, you automatically have?

This excerpt demonstrates Ms. Lewis's attempt to engage students in a discussion that located and explained patterns in the DNA structure. The analysis indicates that students use their experience with the DNA activity, and what they observed in the video to synthesize information and describe the patterns they observed.

Similar to Mr. Kaine's discussion, the discussion followed a teacher-student-teacher interaction pattern. Ms. Lewis's use of follow-up questions makes the discussion different from Mr. Kaine's. In the above excerpt, Ms. Lewis asked questions related to the questions in lines 1 and 2, changing the pattern from IRE to IRF (initiate-respond-follow-up) and engaged the students in trying to make sense of the patterns they had learned (see lines 5, 8 , 
and 10). According to Mehan (1978), Ms. Lewis used simplifying elicitation, or a series of step-by-step questions that did not give cues or prompts. Here, Ms. Lewis asked a series of recall questions, to move the students to a high-level question at the end, "Why do you think they partner up that way?" At various points in the conversation, she inserted questions like "What do you know?" (line 5) and "Why" (line 10), hoping for an explanation. But because the students still struggled with the content, she continued to use simplifying elicitation to assist the students with remembering the content, in order to synthesize it. This point about the struggle with the concept is an important aspect of what distinguishes discussions-or any classroom learning activity - in high school classrooms from those at the elementary or even middle school level. As with Mr. Kaine, the nature of the content, the level of abstraction of the ideas, potentially makes the work of discussing the ideas more complex. Such work is especially challenging in settings where students' previous opportunities to learn have been compromised by lack of instruction in science (Lynch, 2000) or by the neglect of students' language and literacy skills in the disciplinary domains. The challenge of discussing a concept such as DNA, for example, is intensified if one cannot read and understand words and concepts such as double helix, protein synthesis, nucleotide, cytosine, guanine, adenine, or thymine.

In addition, the excerpt shows that students did not address one another, nor respond to each other, and instead continued to respond to the teacher. As in Mr. Kaine's excerpt, Ms. Lewis continued to bear responsibility for the subject matter knowledge and remained at the center of the discussion, providing all feedback and validation to the students. While she tried to shift the knowledge authority onto the students, the students had difficulty synthesizing the content to construct a response that satisfied her, ultimately shifting the authority back to Ms. Lewis in search for an evaluation. In an attempt to build on Theo's offering of "opposites attract" (line 12), Ms. Lewis turned the class attention to the DNA model represented in the textbook and asked the students to analyze the pattern in the arrangement of nucleotides in the sequence (i.e., that adenine and thymine are always paired, as are cytosine and guanine; lines 16-19). She then framed another question for them in line 19: "Why do you think they partner up that way?" Ms. Lewis thus made a clear effort to engage the students in thinking about the mechanisms and processes behind DNA replication, but the abstract nature of the concept, the students' science knowledge, and perhaps their literacy skills, made a generative scientific discussion elusive.

As previously mentioned, this curriculum was still under development, the teachers were new to the curriculum, and we wanted to learn how to improve the curriculum through design-based methods. Therefore, we returned to the curriculum for insight on why Ms. Lewis struggled with this discussion and found that although a rationale was present, the curriculum did not have written strategies to support sustaining this discussion. Nor did the curriculum provide the teachers with enough supports to encourage students to elaborate on what they understood. Comparing the enactment observation and the provided support, we infer that Ms. Lewis was committed to meeting the goal of the discussion, but lack of guidance in the curriculum and the abstract nature of the content hampered her attempts.

That said, we also noted that even when supported with a five-step discussion teaching strategy, Ms. Lewis maintained an IRE-IRF interaction pattern, although the conversation was somewhat livelier than in other discussions, and the students appeared to offer more of their own knowledge to the conversation, as illustrated in this excerpt:

1 Ms. Lewis: This is the framework that we are going to be using for our

2 discussion today. Then I am going to take you through the steps of a

3 question that you are probably very familiar with, then we'll use this

4 framework to take you through the question about myostatin. Alright, 
when you are trying to come to an opinion on an ethical issue, it helps if you have some steps to follow. So, what is an ethical issue? Any ideas?... What might the ethical question be when it comes to steroid use?

8 Ron: Are they good or bad?

9 Ms. Lewis: Go ahead Daniel.

10 Daniel: No, like using it to advance themselves in sports and things.

11 Ms. Lewis: Ok, should we allow people to use them to increase their

12 abilities in sports. Ron, what were you going to say?

13 Ron: Are they healthy or unhealthy?

14 Ms. Lewis: Are they healthy or unhealthy.

15 Aaron: Does it have long-term effects?

16 Ms. Lewis: Does it have long-term effects. So anytime you can work right

17 and wrong, responsibility, duty, obligation, into a question, you are

18 probably talking about something ethical. Step 2 is you have to sometimes

19 think about, or write down what you know. What facts do you know? So

20 what do you know about steroids?

In this interaction, we see more students responding and less evaluation from Ms. Lewis, in large part because she has not asked a question that has a simple factual answer. She does, however, revoice each contribution, thus maintaining her role as discussion monitor and while publicly validating student responses. Still, in the continuation of this conversation, which far more extensive than we can illustrate here, more than one student contributes to the discussion and they offer ideas from their own experience, in large part because the topic of the discussion does not require specialized science knowledge. Note the difference in the interaction when Ms. Lewis shifts the conversation about steroids to their effects and scientific concepts:

1 Ms. Lewis: Ok, now we are going to turn this around and use this to

2 evaluate the issue of myostatin. What does myostatin do?

3 Ron: It doubles your muscles.

4 George: Muscle mass increases?

$5 \quad$ Ms. Lewis: Tell me what, tell me why. What does myostatin do?

6 George: It increases the um. ..

7 Ms. Lewis: How?

8 Students call out answers: Hormone. Genetics.

9 Ms. Lewis: Go back to your article and tell me how... what's actually

10 happening?

Note here that Ms. Lewis is now not interested in the students' opinions and, as a result, is looking for a specific answer. As in Mr. Kaine's class, students toss out what sound like guesses, signaling to Ms. Lewis that they are uncertain of the answer. She makes an interesting and useful teaching move to turn the students back to the article they read, which not only helps to support their use of print texts to develop their knowledge but also allows her to step out of the role of supplier of knowledge. In the following excerpt, it is evident, however, that the students struggle a bit with making sense of the text. Note how Ms. Lewis intervenes in line 3 to support their comprehension of the text:

1 Ms. Lewis: Come on, tell me how, or what myostatin does.

2 Tom: It digests the insulin enzymes. Or proteins that um-

3 Ms. Lewis: Look at the third column. That paragraph, it starts off

4 myostatin (referring to reading they did). 
5 Tom: It's to bring on muscle development in the womb, to bring on

6 muscle growth after birth.

7 Ms. Lewis: Ok.

8 Tom: On the female or on the child?

9 Ms. Lewis: On the child.

10 Tom: That's what I thought.

This exemplar illustrates a useful discussion exchange in which text is used as a source of information, thus moving the discussion away from a strict teacher-focused IRE/F format. However, the exchange appears to occur between Ms. Lewis, Tom, and the text only. In what follows, Ms. Lewis initiates a question, but-perhaps recognizing that the students do not understand the content or perhaps sensing that the interaction is taking more time than she would like-she responds to her own question:

1 Ms. Lewis: So, what's happening in the body? Alright, when you were

2 starting out, you were a single cell. One egg cell, fertilized by a sperm.

3 And that one cell divided into two cells and those two cells divided into 4

4 cells and so on and so forth until you ended up as a fetus made up of

5 trillions of cells.

6 Tom: We are still made of trillions of cells?

7 Ms. Lewis: Yep, we are still made up of trillions of cells. Now, are all

8 those cells the same?

9 Tom: No.

10 Ms. Lewis: No they are not. So what happens along the way is that cells

11 differentiate, meaning they become different kinds of cells. They might

12 become a nerve cell, they might become a muscle, they might become a

13 blood cell.

14 Tom: That's what stem cells do.

15 Ms. Lewis: Yep. This is where myostatin comes in. What myostatin does

16 is what?

The interaction continued in this vein, largely between Ms. Lewis and one student until she forces a response from another student, and solely focused on the function of myostatin in development. In other words, when the conversation shifted to what Ms. Lewis considered factual content (how myostatin works), rather than opinion-based content (the ethics of steroid use), she shifted to a more evaluative role, searching for right answers and correcting the students' responses when they were scientifically inaccurate.

As in Mr. Kaine's enactment, student responses to teacher moves contributed to the discussion patterns observed. In the previous excerpt, the students demonstrated difficulty in articulating responses to the questions asked by the teacher. Because genetics and genomics content are constantly evolving, teachers find it difficult to teach and students find it difficult to learn. In fact, researchers over the past 2 decades have found that instruction and learning in genetics remains conceptually and linguistically difficult in high schools (Tsui \& Treagust, 2006). Although Goodlad (1984) proposed that students think science is important, he also reported they also think it is hard to learn. Ms. Lewis used several representations to help students with conceptual understanding (Cartier \& Stewart, 2000), but the abstract nature of genetics may have made it difficult for the students to make sense of the representations. Although Ms. Lewis persisted and continued to ask, "Why?," the students provided one-word responses that lacked depth and a demonstration of understanding. 
Furthermore, as her students struggled to answer "Why?" questions, Ms. Lewis may have struggled to manage students' ideas and angles on the conversation. According to Scott et al. (2006), some teachers may not know how to vary their instructional procedures to meet the variety of student ideas, responses, and misunderstandings. As a result, Ms. Lewis moved from asking "Why?" and used the textbook images of DNA to support student understanding and formulation of responses. This was a useful teaching move on many levels, but did not necessarily shift the discussion from a search for the scientifically accurate answer to a more open-ended discussion about how and why myostatin works.

Although not as frequent as in Mr. Kaine's classroom, Ms. Lewis's students provided one-word responses to recall questions and were given evaluative feedback, creating an authoritative discussion dynamic. Of the three lessons observed, only one of Ms. Lewis's lessons consisted mainly of IRE recitation discussions. However, Ms. Lewis asked follow-up questions as an attempt to increase student participation and explanation more frequently than did Mr. Kaine. During open-ended discussions (Table 2, column 5), Ms. Lewis shifted the IRE format toward richer more process-based explanations and interactions by asking follow-up questions and requiring students to provide evidence for their responses. Students in Lewis's classroom, however, did not address one another while asking for or providing additional information, nor did students confront each other's ideas. In such cases, Ms. Lewis continued to lead the discussions and insert evaluative comments student responses.

In summary, both teachers attempted to engage students in discussion about the genomics concepts, but the teachers varied in their success with discussions. Both teachers tended to rely on initiation-response-evaluation formats, although Ms. Lewis made more obvious attempts to engage students in discussing why certain processes, mechanisms, and phenomena might work the way they do.

\section{DISCUSSION}

\section{High Schools and Scientific Discussions: High School Discussions Are Unique and Complex}

The goal of this study was to examine the nature of discussions in a high school projectbased science classroom with the underlying question of whether embedded discussion supports provided sufficient support to promote inquiry-based discussions in such settings. On the basis of what we observed in Mr. Kaine's and Ms. Lewis's classrooms, together with other studies of middle and high school settings (Barton, Tan, \& Rivet, 2008; Moje et al., 2004; Moje \& Speyer, 2008), we hypothesize that high school classrooms present additional challenges to engaging in dialogic discussion in addition to those encountered in elementary and middle school classrooms (Hadjioannou, 2007).

For example, one common concern expressed by secondary school teachers is the need to cover content quickly in abbreviated time periods across the school day (Powell, Farrar, \& Cohen, 1985; Sizer, 1984; R. T. Vacca \& J. Vacca, 2004). In the case of Ms. Lewis and Mr. Kaine, they each experienced time constraints in enacting the curriculum as they worked to get through the curriculum in a timely fashion so that they could be seen as achieving state content standards. Both teachers taught in school districts that emphasized state standards and high-stakes testing. When faced with the novel experience of leading scientific discussions about difficult content, we speculate that the teachers turned to a discussion pattern that was familiar and that was certain to cover the required subject matter in the allotted amount of time. 
This study extends the work of Davis and Krajcik (2005) by demonstrating the need to help teachers accomplish content coverage within time constraints of testing and state standards by clearly articulating, in the curriculum, the goals of dialogic interactions and how teachers and students roles can be altered to adapt to the changes in authoritative discourse. Such guidance, coupled with the professional development opportunities (see following section), might allow the teacher to maintain a sense of autonomy during instruction, but provide clear goals and suggested strategies to initiate and sustain the process to meet the demands of a vast set of content standards.

In addition to the demand to cover a broad range of content concepts, secondary school teachers face the challenge of connecting increasingly abstract disciplinary conceptsin this case concepts such as DNA, chromosomes, genes, and proteins, all phenomena invisible to the naked eye and for which it is difficult to construct hands-on inquiry-to the everyday lives of young people. Jimenez-Aleixandre et al. (2000) argue specifically that genetics is one of the most difficult topics in biology to understand, but the fact is that all scientific concepts, when studied at more and more advanced levels, require a certain amount of abstraction. In this study, student generally struggled with making connections between the DNA and the trait level. Add to the abstraction of science the fact that at the high school level, many students' social lives become more demanding than at younger ages (Moje, 2002). Regardless of the students involved, connecting abstract advanced science concepts to concrete everyday social lives is an enormous challenge for teachers. Combine this challenge with the difficulty of engaging students in hands-on inquiry of abstract phenomena, and it may be no surprise that "pedagogy of telling" (Sizer, 1984) prevails.

Finally, it may be that the teachers struggled with connecting everyday student discourses, instructional discourse, and the scientific discourses of the genomics. According to HiltonBrown (2004), urban students in his study had difficulty appropriating scientific discursive practices due to cultural conflicts with science. Similarly, Moje et al. (2001) show that in secondary school project-based science classrooms, student everyday discourses may compete with scientific discourses in the classroom. In Mr. Kaine's and Ms. Lewis's classroom, students may have had trouble balancing the increasingly advanced discourse of science required in high school classrooms and their own cultural discourses, and thus limited their participation during scientific discussions to one-word and/or indirect responses. In addition, the teachers may not have known how to navigate the discourse they encountered and how to encourage students' participation.

In summary, our analyses and review of the literature demonstrated that the complexity and multifaceted nature of scientific discussions and high school classrooms require consistent and specific supports that provide the teacher with (a) a rationale that explains the purpose of the discussion, (b) questions that stimulate discussion rather than prompt right/wrong answers, (c) strategies for teaching adolescents how to engage in dialogic, inquiry discussions, and (d) strategies to help the teacher guide discussions without taking them over, especially when working with students unaccustomed to such practices.

\section{Thinking Differently About Curriculum Development: Incorporating Professional Development and Design-Based Research}

Curriculum design in this study was an iterative process; research on student and teacher engagement resulting from discussions informed curricular decisions and modifications, and how to support future enactments, and as a result, has directed us to new areas of 
research interests. Our work was guided by our commitment to help teachers and students participate in rich and meaningful scientific discussions that not only encourage student understanding and synthesis of subject matter but also help students develop discursive practices in science. One consideration is that while curriculum materials can embed written supports that can provide guidance for teachers during real-time instruction, the complexity of dialogic, inquiry discussions makes them difficult to capture and scaffold in printbased curriculum materials alone. Supposing that curriculum materials are enough for the enactment of rich discussions suggests that text alone is a fixed representation of the enacted curriculum and can control classroom instruction (Remillard, 2005). In this development and research process, we did not provide teachers with professional development workshops that would allow them to participate in study groups, or contextualize their learning within the conditions of their classrooms. During the development of the curriculum, we intended the written embedded supports to be sufficient as real-time enactment guidance. Owing to the complexities of discussions, creating a learning environment that values and welcomes learning through discourse, which is in itself multifaceted, is enormously challenging. Furthermore, in addition to the complexity of classroom discourse, one particular aspect of the context worthy of close study suggested by our analysis is how the abstract nature of science content at the high school level, coupled with the existing norms and practices for classroom interaction evident in many secondary school settings (Goodlad, 1984; Sizer, 1984), shapes teachers' abilities and inclinations to engage students in inquiry-oriented, dialogic discussions.

A second consideration is that written supports may in fact constrain instruction. In a study by Stake and Easley (1978), they found that reform efforts were largely ineffective because the curriculum developers did not anticipate the ways in which teachers might misinterpret the curriculum materials, resulting in teacher adaptations that misrepresented the curricular goals, or teacher resistance that eventually led to what was familiar and traditional instruction. As the teachers in this study struggled to sustain the discussions, while attempting to assess student conceptual understanding and maintain fidelity to the curriculum, both teachers may have consulted the curriculum, in search for strategies to help them achieve the discussion goals. Because supports were not consistent throughout the curriculum and the teachers had no prior experience with the curriculum or a hand in its development, they may have limited their discussion pedagogy to what was offered in the curriculum.

In line with existing efforts to enhance professional development efforts (Putnam \& Borko, 2000) through methods such as lesson study (Fernandez \& Yoshida, 2004) and improved curriculum materials (Kesidou \& Roseman, 2002), we would like to explore how professional development could provide better support for the enactment of rich and open-ended discussions in high school inquiry science classrooms. Effective professional development conditions and practices consist of reform-oriented activities, such as teacher study groups, more frequent professional development sessions, and the collective participation of teachers from the same school (Penuel, Fishman, Yamaguchi, \& Gallagher, 2007). Professional development workshops can be interactive with teaching practices and allow for multiple cycles of presentation and assimilation of, and reflection on knowledge (Ball \& Cohen, 1996; Blumenfeld, Soloway, Marx, Guzdial, \& Palincsar, 1991; Putnam \& Borko, 2000). Such a process extends written embedded supports by changing them from fixed directions to guides teachers can adapt according to the culture and context of their classrooms. Professional development can help teachers make decision on their instruction, make revisions to the curriculum, and create specialized supports for classroom-specific enactments. 
In addition, our findings suggest the need for additional forms of design research. This study gives insight to the need for continued design-based research (Cobb, Confrey, diSessa, Lehrer, \& Schauble, 2003). Design research is an iterative process that involves tightly linked design-analysis-redesign cycles that move toward both learning and activities and/or artifacts for improvement (Shavelson, Phillips, Towne, \& Feuer, 2003). This includes understanding the kinds of tasks that high school students participate in; the discourse that is encouraged (implicitly or explicitly); the norms of participation in high school classrooms; the available tools such as texts, images, and digital technologies; and the practical means that a teachers uses to orchestrate relations among these elements (Cobb et al., 2003). In our analysis, we pointed to several potential reasons for the difficulties high school teachers faced while enacting discussions - from student content knowledge to curricular pressures to a history of IRE participation norms. We also examined why the embedded discussion questions and supports may not have been helpful. Through design-experimentation, we could look more closely at how different curricular features inform classroom interactions and at how classroom social and organizational norms and contexts shape curriculum enactment.

In conclusion, the findings in this study showed that even when the teachers committed to the goals of the curriculum and consulted the curriculum for guidance, they continued to experience tensions between authoritative and dialogic, often reverting to IRE/F discussion patterns. At a time where teachers are being held accountable for promoting inquiry skills like communication in science, science educators and curriculum developers should consider the social, affective, and motivational aspects of teachers' curriculum use and of student participation and response to teacher instruction. We need to construct materials that not only speak to teachers, but also include them in the conversation (Ball \& Cohen, 1996). Increased and expanded discussion questions and supports for teachers in high school project-based science curricular materials are necessary to help teachers understand the reasons behind suggested discussions and how to enact them. Furthermore, written curriculum materials alone may not be able to speak to the complex social structures, arrangements, and content concepts of high school science classrooms, especially when it comes to fostering dialogic discussions. Professional development activities and rich design experiments that explicate the host of challenges of high school inquiry-based science will be necessary to better support teachers as they attempt to engage students in the difficult task of discussing abstract science concepts.

\section{APPENDIX A: SUMMARY OF EDUCATIVE FEATURES FOR ALL DISCUSSIONS}

We provide a holistic view of curricular supports and resulting teacher enactment. For each lesson in the curriculum (column 1), the amount of suggested curricular discussions is documented (column 2). For each discussion, we describe the discussion goals (column 3), whether a rationale was present (column 4), and whether strategies for the discussion were provided (column 5). After watching videos of enactment, we documented discourse patterns and the use of inquiry practices for Ms. Lewis (column 6) and Mr. Kaine (column 7). 


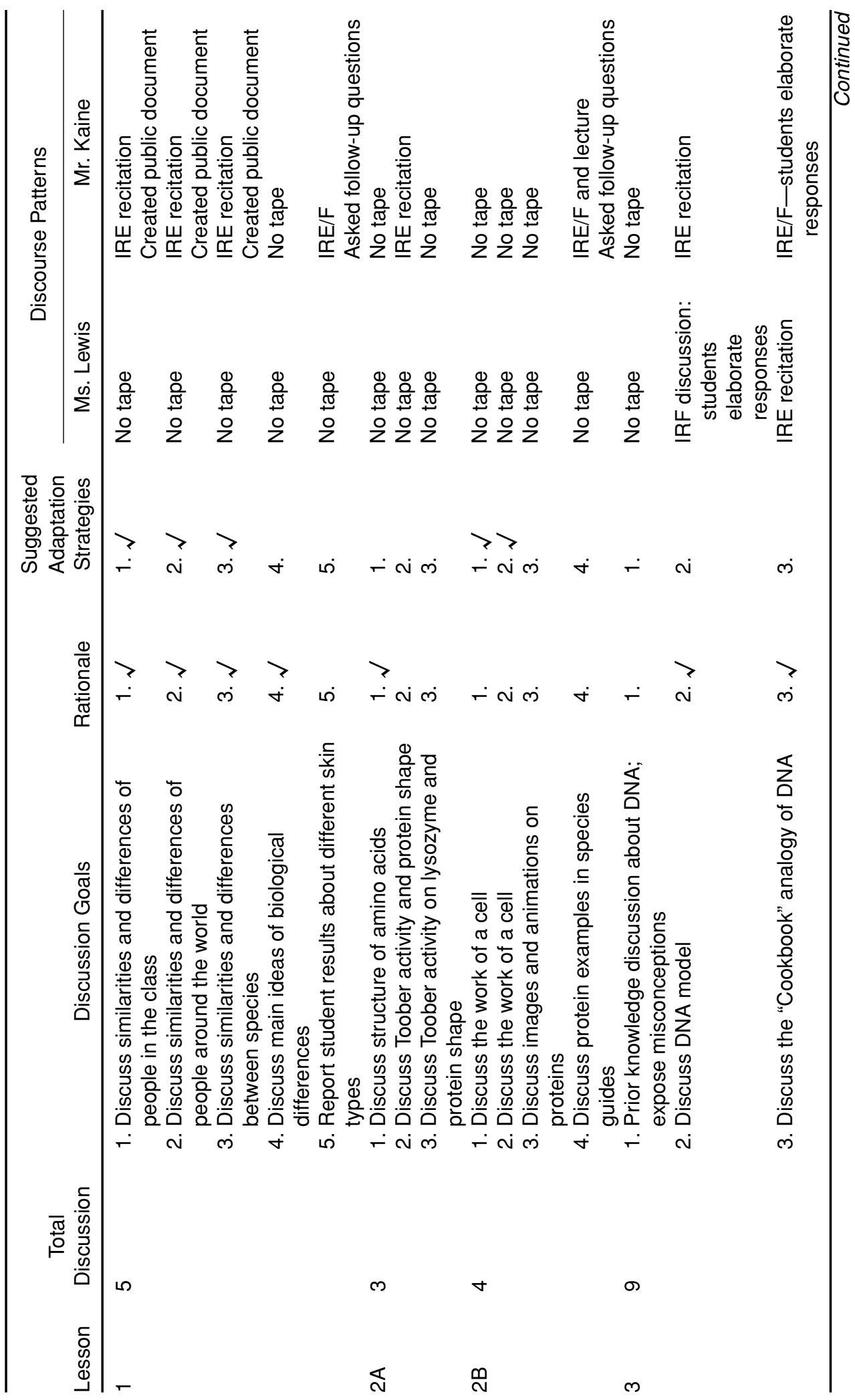




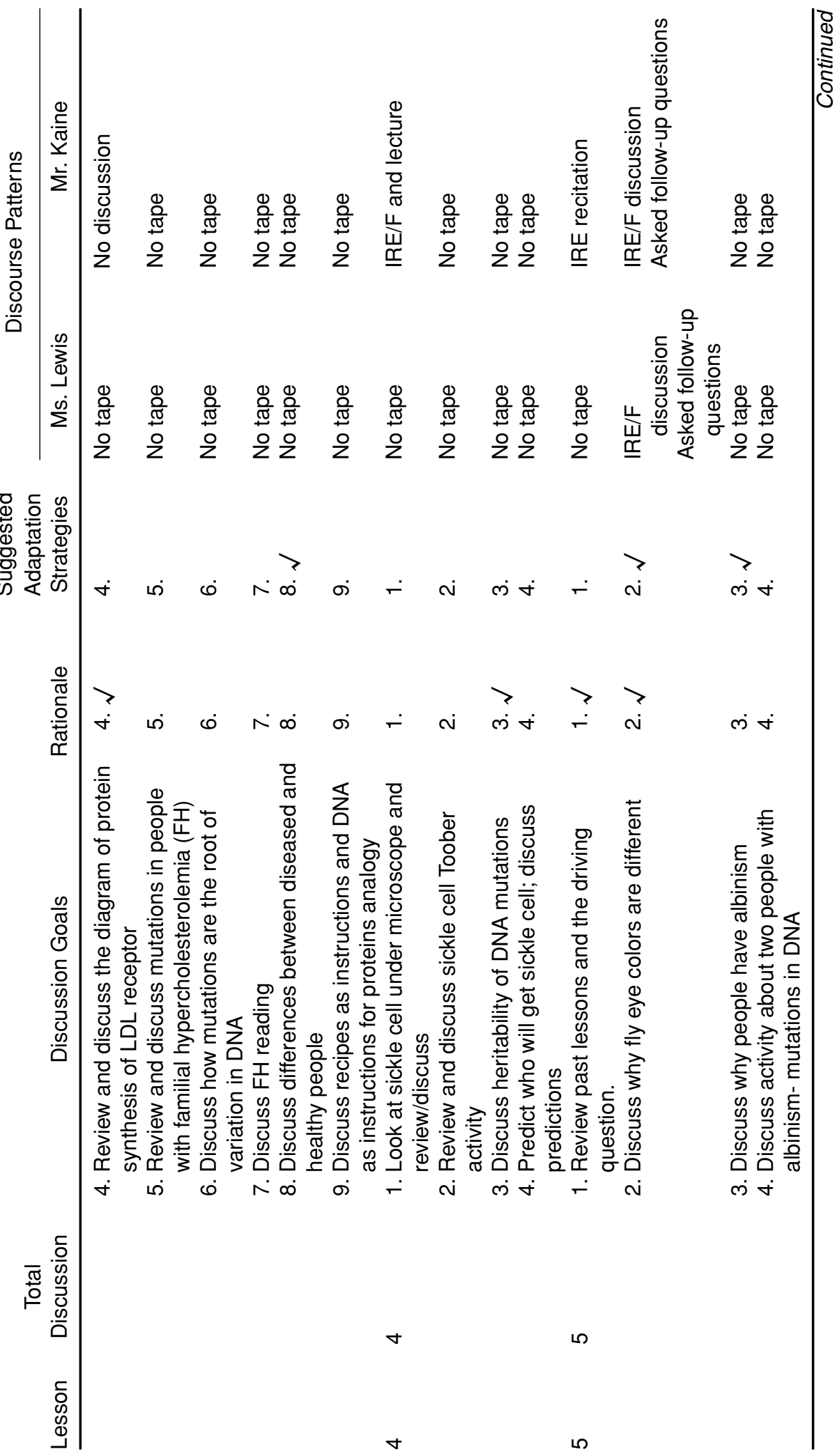




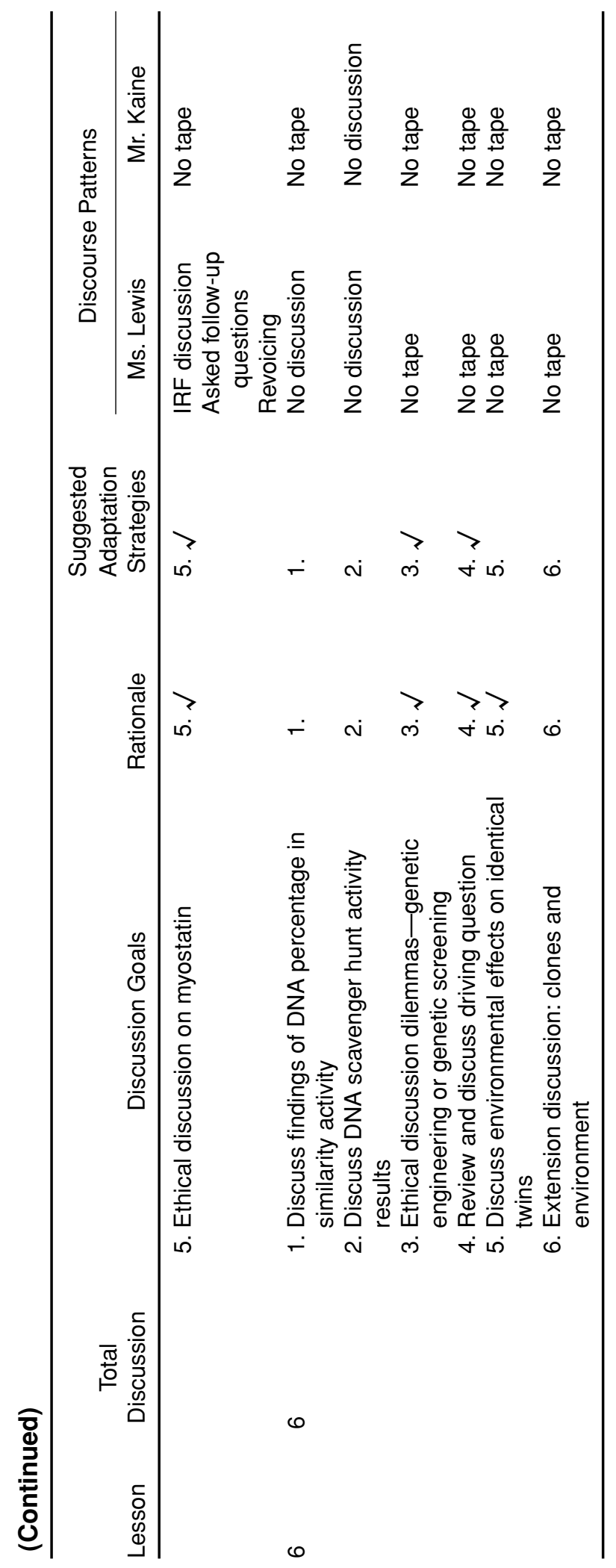




\section{APPENDIX B: APPLIED CODING SCHEME: MR. KAINE DISCUSSION EXCERPT. THE DISCOURSE ANALYSIS OF MR. KAINE'S CLASSROOM DISCUSSION ON SICKLE CELL}

\begin{tabular}{|c|c|c|c|}
\hline Sequences & Discussion & Move & Function \\
\hline \multirow[t]{7}{*}{$\# 1$} & $\begin{array}{l}\text { 1. Mr. Kaine: Now we look } \\
\text { deeper, we look at the level } \\
\text { of the protein. What do we } \\
\text { see happening inside the } \\
\text { cell to hemoglobin protein? } \\
\text { What's it doing? }\end{array}$ & Initiation & $\begin{array}{l}\text { Question. Starts a new } \\
\text { exchange. New } \\
\text { question. This is a } \\
\text { process question. } \\
\text { High order-analysis/ } \\
\text { explanation. }\end{array}$ \\
\hline & $\begin{array}{l}\text { 2. Grace: Multiplying? } \\
\text { Dividing? }\end{array}$ & Response & $\begin{array}{l}\text { Fact response that } \\
\text { acknowledges the } \\
\text { question. [Guessing?] }\end{array}$ \\
\hline & $\begin{array}{l}\text { 3. Mr. Kaine: Its not that there } \\
\text { is more hemoglobin. It's } \\
\text { just that the hemoglobin is, } \\
\text { has a different shape right? } \\
\text { Its not normal hemoglobin, } \\
\text { its mutant hemoglobin. }\end{array}$ & Evaluation & $\begin{array}{l}\text { Rejection with } \\
\text { justification-low level. }\end{array}$ \\
\hline & $\begin{array}{l}\text { 4. Mr. Kaine: So, you can say } \\
\text { that, if you look at the level } \\
\text { of protein, there is one } \\
\text { amino acid that's different. } \\
\text { You all saw that in the last } \\
\text { figure. Right, right here? } \\
\text { (Points to powerpoint) One } \\
\text { amino acid change causes } \\
\text { the change in the shape of } \\
\text { the hemoglobin, a small } \\
\text { difference. And then its } \\
\text { starts doing this. Right? A } \\
\text { small change in the shape } \\
\text { and it starts glomming } \\
\text { together to make crystals. }\end{array}$ & & $\begin{array}{l}\text { Gives the answer for } \\
\text { student. }\end{array}$ \\
\hline & $\begin{array}{l}\text { 5. Mr. Kaine: So, how would } \\
\text { we say that? Very simply, } \\
\text { just the hemoglobin is } \\
\text { different from normal } \\
\text { hemoglobin. A different } \\
\text { shape. }\end{array}$ & Follow-up & $\begin{array}{l}\text { Conventional explanation } \\
\text { question. Asks another } \\
\text { sequential question, } \\
\text { then answers it } \\
\text { himself. }\end{array}$ \\
\hline & $\begin{array}{l}\text { 6. Gary: Cuz of the amino } \\
\text { acids? }\end{array}$ & Response & Requests clarification. \\
\hline & $\begin{array}{l}\text { 7. Mr. Kaine: Because of that } \\
\text { one amino acid difference. }\end{array}$ & Follow-up & Gives clarification. \\
\hline
\end{tabular}


(Continued)

\begin{tabular}{|c|c|c|c|}
\hline Sequences & Discussion & Move & Function \\
\hline & $\begin{array}{l}\text { 8. I think that would be } \\
\text { perfect. If you write down } \\
\text { that there is one amino acid } \\
\text { difference in the } \\
\text { hemoglobin protein, it's a } \\
\text { mutant form of it and it } \\
\text { doesn't work exactly right, } \\
\text { that would be your } \\
\text { explanation at the level of } \\
\text { the protein. }\end{array}$ & Follow-up & $\begin{array}{l}\text { Answers the question for } \\
\text { the student. Also } \\
\text { provides elaboration } \\
\text { and explanation for } \\
\text { student. Tells the } \\
\text { students what to write } \\
\text { down. }\end{array}$ \\
\hline \multirow[t]{9}{*}{ \#2 } & $\begin{array}{l}\text { 9. Mr. Kaine: The next } \\
\text { question is, what causes } \\
\text { there to be a different } \\
\text { protein? What is it that } \\
\text { determines what the } \\
\text { protein is going to be? }\end{array}$ & Initiation & $\begin{array}{l}\text { Question. Conventional } \\
\text { explanation question. } \\
\text { High level. }\end{array}$ \\
\hline & 10. Michael: DNA? & Response & $\begin{array}{l}\text { Fact that acknowledges } \\
\text { the question }\end{array}$ \\
\hline & $\begin{array}{l}\text { 11. Mr. Kaine: The DNA. } \\
\text { 12. Mr. Kaine: So, what } \\
\text { should we write at the DNA } \\
\text { level? }\end{array}$ & $\begin{array}{l}\text { Evaluation } \\
\text { Follow-up }\end{array}$ & $\begin{array}{l}\text { Accept. Low level. } \\
\text { Question. }\end{array}$ \\
\hline & 13. Michael: A change. & Response & $\begin{array}{l}\text { Fact-acknowledge } \\
\text { question. }\end{array}$ \\
\hline & 14. Mr. Kaine: A change. & Evaluation & Accept. Low level. \\
\hline & $\begin{array}{l}\text { 15. What kind of change is it? } \\
\text { You told me- }\end{array}$ & Follow-up & $\begin{array}{l}\text { Question-wants more } \\
\text { information. }\end{array}$ \\
\hline & 16. Student: -A substitution. & Response & $\begin{array}{l}\text { Fact-acknowledges } \\
\text { question. }\end{array}$ \\
\hline & $\begin{array}{l}\text { 17. Mr. Kaine: Yep, you told } \\
\text { me what kind of } \\
\text { substitution. You said it was } \\
\text { a mutation and that it was a } \\
\text { substitution mutation. }\end{array}$ & & Continues explanation. \\
\hline & $\begin{array}{l}\text { 18. Mr. Kaine: So, folks what } \\
\text { you can write for the last } \\
\text { one, gene or DNA level, } \\
\text { you can say the gene has } \\
\text { changed. That there is one } \\
\text { letter that's different. It's a } \\
\text { substitution mutation. And } \\
\text { that's what causes the } \\
\text { protein to be different. } \\
\text { Don't forget that genes are } \\
\text { the instructions for how to } \\
\text { make a protein. }\end{array}$ & Follow-up & $\begin{array}{l}\text { Gives answer for } \\
\text { students. Tells } \\
\text { students what to write. }\end{array}$ \\
\hline
\end{tabular}




\section{APPENDIX C: APPLIED CODING SCHEME: MS. LEWIS DISCUSSION EXCERPT. THE DISCOURSE ANALYSIS OF MS. LEWIS'S CLASSROOM DISCUSSION ON DNA STRUCTURE}

\begin{tabular}{|c|c|c|c|}
\hline Sequences & Discussion & Move & Function \\
\hline \multirow[t]{15}{*}{$\# 1$} & $\begin{array}{l}\text { 1. Ms. Lewis: Ok. So, if you } \\
\text { got blue, what do you know } \\
\text { about some other parts of } \\
\text { the DNA? Do you know } \\
\text { what's going to be above or } \\
\text { below blue necessarily? }\end{array}$ & $\begin{array}{l}\text { Initiating } \\
\text { question }\end{array}$ & $\begin{array}{l}\text { Rephrase of initial } \\
\text { question from nuclear } \\
\text { exchange-simplifies } \\
\text { the question. Low-level } \\
\text { recall question. }\end{array}$ \\
\hline & 2. Class: No. & Response & $\begin{array}{l}\text { Fact response } \\
\text { acknowledges. }\end{array}$ \\
\hline & $\begin{array}{l}\text { 3. Ms. Lewis: No, not } \\
\text { necessarily. But what do } \\
\text { you know? }\end{array}$ & $\begin{array}{l}\text { Evaluate } \\
\text { and } \\
\text { follow-up }\end{array}$ & $\begin{array}{l}\text { Teacher wants more } \\
\text { information from } \\
\text { students. }\end{array}$ \\
\hline & $\begin{array}{l}\text { 4. Effie: What will be across } \\
\text { from it. That it won't be an } \\
\text { orange or another blue? }\end{array}$ & Response & $\begin{array}{l}\text { Fact-acknowledges } \\
\text { questions. }\end{array}$ \\
\hline & $\begin{array}{l}\text { 5. Ms. Lewis: What's always } \\
\text { across from blue? }\end{array}$ & Follow-up & $\begin{array}{l}\text { Teacher wants more } \\
\text { information from } \\
\text { students. }\end{array}$ \\
\hline & $\begin{array}{l}\text { 6. Class: (answers vary) } \\
\text { Orange; green. }\end{array}$ & Response & $\begin{array}{l}\text { Fact-acknowledges } \\
\text { question. }\end{array}$ \\
\hline & 7. Ms. Lewis: Orange. Why? & Follow-up & $\begin{array}{l}\text { Teacher wants more } \\
\text { information from } \\
\text { students. }\end{array}$ \\
\hline & 8. Class: (Answers vary) & Response & Answer. \\
\hline & 9. Theo: opposites attract. & Response & $\begin{array}{l}\text { Fact-acknowledges } \\
\text { question. }\end{array}$ \\
\hline & $\begin{array}{l}\text { 10. Ms. Lewis: So, you think } \\
\text { they are opposites? Ok, } \\
\text { do me a favor. Open your } \\
\text { books to page } 5 \text {, lesson } 3 \text {. }\end{array}$ & Follow-up & $\begin{array}{l}\text { Null evaluation/ } \\
\text { Acknowledge. }\end{array}$ \\
\hline & $\begin{array}{l}\text { 11. Alright, you see that } \\
\text { model of DNA? }\end{array}$ & Initiation & Question. \\
\hline & 12. Class: Yes. & Response & $\begin{array}{l}\text { Fact-acknowledges } \\
\text { question. }\end{array}$ \\
\hline & $\begin{array}{l}\text { 13. Ms. Lewis: You see how } \\
\text { Cs and Gs are always } \\
\text { across from each other } \\
\text { and As and Ts are always } \\
\text { across from each other? }\end{array}$ & Follow-up & $\begin{array}{l}\text { Teacher wants more } \\
\text { information from } \\
\text { students. }\end{array}$ \\
\hline & 14. Class: Mmhmm. & Response & Acknowledge. \\
\hline & $\begin{array}{l}\text { 15. Ms. Lewis: Why? Why do } \\
\text { you think they partner up } \\
\text { in that way? }\end{array}$ & Follow-up & $\begin{array}{l}\text { Conventional explanation } \\
\text { question. }\end{array}$ \\
\hline
\end{tabular}




\section{REFERENCES}

Alvermann, D. E., Dillon, D. R., \& O’Brien, D. G. (1987). Discussion strategies for content area reading. In D. E. Alvermann, D. R. Dillon, \& D. G. O'Brien (Eds.), Using discussion to promote reading comprehension. Newark, DE: International Reading Association.

American Association for the Advancement of Science. (1993). Benchmarks for science literacy. New York: Oxford University Press.

Ball, D. L., \& Cohen, D. K. (1996). Reform by the book: What is: Or what might be: The role of curriculum materials in teacher learning and instructional reform? Educational Researcher, 25(9), 6-8, 14.

Barron, B. J. S., Schwartz, D. L., Vye, N. J., Moore, A., Petrosino, A., Zech, L., et al. (1998). Doing with understanding: Lessons from research on problem- and project-based learning. Journal of the Learning Sciences, $7(3-4), 271-311$.

Barton, A. C., Tan, E., \& Rivet, A. (2008). Creating hybrid spaces for engaging school science among urban middle school girls. American Educational Research Journal, 45, 68-103.

Blumenfeld, P., Marx, R., \& Harris, C. (2006). Learning environments (Vol. 4). Hoboken, NJ: Wiley.

Blumenfeld, P., Marx, R. W., Patrick, H., Krajcik, J., \& Soloway, E. (1997). Teaching for understanding. In B. J. Biddle (Ed.), International handbook of teachers and teaching (pp. 819-878). Dordrecht, The Netherlands: Kluwer.

Blumenfeld, P., Soloway, E., Marx, R., Guzdial, M., \& Palincsar, A. (1991). Motivating project-based learning: Sustaining the doing, supporting the learning. Educational Psychologist, 26(3/4), 369-398.

Candela, A. (1999). Students' power in classroom discourse. Linguistics and Education, 10(2), 139-163.

Caravita, S., \& Hallden, O. (1994). Reframing the problem of conceptual change. Learning and Instruction, 4, 89-111.

Cartier, J. L., \& Stewart, J. (2000). Teaching the nature of inquiry: Further developments in a high school genetics curriculum. Science and Education, 9(3), 247-267.

Chin, C. (2007). Teacher questioning in science classrooms: Approaches that stimulate productive thinking. Journal of Research in Science Teaching, 44(6), 815-843.

Cobb, P., Confrey, J., diSessa, A., Lehrer, R., \& Schauble, L. (2003). Design experiments in educational research. Educational Researcher, 32(1), 9-13.

Crawford, T., Kelly, G. J., \& Brown, C. (2000). Ways of knowing beyond facts and laws of science: An ethnographic investigation of student engagement in scientific practices. Journal of Research in Science Teaching, 37(3), $237-258$.

Davis, E., \& Krajcik, J. (2005). Designing educative curriculum materials to promote teacher learning. Educational Researcher, 34(3), 3-14.

Erickson, F. (1986). Qualitative methods in research on teaching. In M. C. Wittrock (Ed.), Handbook of research on teaching (3rd ed., pp. 119-161). New York: MacMillan Press.

Fernandez, C., \& Yoshida, M. (2004). Lesson study: A Japanese approach to improving mathematics teaching and learning. Mahwah, NJ: Erlbaum.

Fishman, B., \& Davis, E. A. (2006). Teacher learning research and the learning sciences. In R. K. Sawyer (Ed.), Cambridge handbook of learning sciences (pp. 535-550). New York: Cambridge University Press.

Gee, J. P. (1996). Social linguistics and literacies: Ideology in discourses (2nd ed.). London: Falmer.

Goodlad, J. I. (1984). A place called school: Prospects for the future. New York: McGraw-Hill.

Greeno, J., \& Middle School Mathematics Through Applications Project Group. (1998). The situativity of knowing, learning, and research. American Psychologist, 53(1), 5-26.

Hadjioannou, X. (2007). Bringing the background to the foreground: What do classroom environments that support authentic discussions look like? American Educational Research Journal, 44(2), 370-399.

Hilton-Brown, B. A. (2004). Discursive identity: Assimilation into the culture of science and its implication for minority students. Journal of Research in Science Teaching, 41(8), 810-834.

Jimenez-Aleiandre, M. P., Rodriguez, A. B., \& Duschl, R. (2000). "Doing the science lesson" or "doing science": Argument in high school genetics. Science Education, 84(6), 757-792.

Kelly, G., \& Green, J. (1998). The social nature of knowing: Toward a sociocultural perspective on conceptual change and knowledge construction. In B. Guzzetti \& C. Hynd (Eds.), Perspectives on conceptual change: Multiple ways to understand knowing and learning in a complex world. London: Routledge.

Kesidou, S., \& Roseman, J. E. (2002). How well do middle school science programs measure up? Findings from Project 2061's curriculum review. Journal of Research in Science Teaching, 39(6), 522-549.

Krajcik, J., \& Blumenfeld, P. (2006). Project-based learning. In R. K. Sawyer (Ed.), The Cambridge handbook of the learning sciences (pp. 317-334). New York: Cambridge University Press.

Krajcik, J., Blumenfeld, P., Marx, R. W., Bass, K. M., Fredricks, J., \& Soloway, E. (1998). Inquiry in project-based science classrooms: Attempts by middle school students. Journal of the Learning Sciences, 7(3/4), 313-350. 
Krajcik, J., Czerniak, C. M., \& Berger, C. F. (2002). Teaching science in elementary and middle school classrooms: A project based approach. New York: McGraw-Hill.

Kuhn, L., Kenyon, K. O., \& Reiser, B. J. (2006). Fostering scientific argumentation by creating a need for students to attend to each other's claims and evidence. Paper presented at International Conference of the Learning Sciences (ICLS), Bloomington, IN.

Lemke, J. (1990). Talking science: Language, learning, and values. Norwood, NJ: Ablex.

Lynch, S. (2000). Equity and science education reform. Mahwah, NJ: Erlbaum.

Magnusson, S., Palincsar, A. S., \& Templin, M. (2004). Community, culture, and conversation in inquiry-based science instruction. In L. B. Flick \& N. G. Lederman (Eds.), Scientific inquiry and nature of science (pp. 131155). Dordrecht, The Netherlands: Kluwer.

McNeill, K., Lizotte, D. J., Krajcik, J., \& Marx, R. (2006). Supporting students' construction of scientific explanations by fading scaffolds in instructional materials. Journal of the Learning Sciences, 15(2), 153-191.

Mehan, H. (1978). Structuring school structure. Harvard Educational Review, 48(1), 32-64.

Mehan, H. (1979). Learning lessons: Social organization in the classroom. Cambridge, MA: Harvard University Press.

Moje, E., Collazo, T., Carillo, R., \& Marx, R. W. (2001). “Maestro, what is 'quality'?”: Language, literacy, and discourse in project-based science. Journal of Research in Science Teaching, 38(4), 469-498.

Moje, E. B. (1997). Exploring discourse, subjectivity, and knowledge in chemistry class. Journal of Classroom Interaction, 32, 35-44.

Moje, E. B. (2002). But where are the youth: Integrating youth culture into literacy theory. Educational Theory, 52, 97-120.

Moje, E. B., Ciechanowski, K. M., Kramer, K. E., Ellis, L. M., Carrillo, R., \& Collazo, T. (2004). Working toward third space in content area literacy: An examination of everyday funds of knowledge and discourse. Reading Research Quarterly, 39(1), 38-71.

Moje, E. B., \& Speyer, J. (2008). The reality of challenging texts in high school science and social studies: How teachers can mediate comprehension. In K. Hinchman \& H. Thomas (Eds.), Best practices in adolescent literacy instruction (pp. 185-211). New York: Guilford Press.

Nassaji, H., \& Wells, G. (2000). What's the use of 'triadic dialogue'?: An investigation of teacher-student interaction. Applied Linguistics, 21(3), 376-406.

National Research Council. (1996). National Science Education Standards. Washington, DC: National Academic Press.

National Research Council. (2000). Inquiry and the National Science Education Standards. Washington, DC: National Research Council.

O'Brien, D. G., Stewart, R. A., \& Moje, E. B. (1995). Why content literacy is difficult to infuse into the secondary school: Complexities of curriculum, pedagogy, and school culture. Reading Research Quarterly, 30, 442-463.

Penuel, W., Fishman, B., Yamaguchi, R., \& Gallagher, L. (2007). What make professional development effective? Strategies that foster curriculum implementation. American Educational Research Journal, 44(4), 921-958.

Polman, J. L. (2000). Designing project-based science: Connecting learning through guided inquiry. New York: Teachers College Press.

Polman, J. L. (2004). Dialogic activity structures for project-based learning environments. Cognition and Instruction, 22(4), 431-466.

Powell, A. G., Farrar, E., \& Cohen, D. K. (1985). The shopping mall high school: Winners and losers in the educational marketplace. Boston: Houghton-Mifflin.

Putnam, R., \& Borko, H. (2000). What do new views of knowledge and thinking have to say about research on teacher learning? Educational Researcher, 29(1), 4-15.

Remillard, J. T. (2005). Examining key concepts in research on teachers' use of mathematics curricula. Review of Educational Research, 75(2), 211-246.

Scott, P. H., Mortimer, E. F., \& Aguiar, O. G. (2006). The tension between authoritative and dialogic discourse: A fundamental characteristic of meaning making interactions in high school science lessons. Science Education, 90(4), 605-631.

Shavelson, R. J., Phillips, D. C., Towne, L., \& Feuer, M. J. (2003). On the science of education design studies. Educational Researcher, 32(1), 23-28.

Singer, J., Marx, R. W., Krajcik, J., \& Chambers, J. C. (2000). Constructing extended inquiry projects: Curriculum materials for science education reform. Educational Psychologist, 35(3), 165-178.

Sizer, T. R. (1984). Horace's compromise: The dilemma of the American high school. Boston: Houghton Mifflin. 
Solomon, T. C., van Der Kerkhof, M., \& Moje, E. B. (in press). When is a detail seductive? Examining text and the role of interest in middle-school students, scientific literacy development. In A. Rodriguez (Ed.), Science education as a pathway to teaching language literacy. Rotterdam, The Netherlands: Sense Publishers.

Stake, R. E., \& Easley, J. (1978). Case studies in science education. Urbana-Champaign: University of Illinois.

Strauss, A., \& Corbin, J. (1998). Basics of qualitative research: Procedures and techniques for developing grounded theory (2nd ed.). Thousand Oaks, CA: Sage.

Tharp, R., \& Gallimore, R. (1991). The instruction conversation: Teaching and learning in social activity. Santa Cruz, CA: National Center for Research on Cultural Diversity and Second Language Learning.

Tsui, C.-Y., \& Treagust, D. F. (2006). Understanding genetics: Analysis of secondary students conceptual status. Journal of Research in Science Teaching, 44(2), 205-235.

Vacca, R. T., \& Vacca, J. (2004). Content area reading: Literacy and learning across the curriculum (8th ed.). New York: Allyn \& Bacon.

Vygotsky, L. S. (1986). Thought and language (A. Kozulin, Trans.). Cambridge: The Massachusetts Institute of Technology.

Wells, G., \& Mejia-Arauz, R. (2006). Dialogue in the classroom; Journal of the Learning Sciences, 15(3), $379-428$.

Wertsch, J. V. (1995). The need for action in scoiocultural research. In J. V. Wertsch, P. DelRio, \& A. Alvarez (Eds.), Sociocultural studies of mind (pp. 56-74). New York: Cambridge University Press. 